\title{
AUTHOR CORRECTION OPEN Author Correction: Data centre water consumption
}

\section{David Mytton (iD)}

npj Clean Water (2021)4:49; https://doi.org/10.1038/s41545-021-00140-3

Correction to: npj Clean Water https://doi.org/10.1038/s41545-02100101-w, published online 15 February 2021

In the original version of the Article, reference 17 was incorrect and the link redirected to the wrong publication. This has now been corrected in the HTML and PDF versions of the Article.

\begin{abstract}
(i) Open Access This article is licensed under a Creative Commons Attribution 4.0 International License, which permits use, sharing, adaptation, distribution and reproduction in any medium or format, as long as you give appropriate credit to the original author(s) and the source, provide a link to the Creative Commons license, and indicate if changes were made. The images or other third party material in this article are included in the article's Creative Commons license, unless indicated otherwise in a credit line to the material. If material is not included in the article's Creative Commons license and your intended use is not permitted by statutory regulation or exceeds the permitted use, you will need to obtain permission directly from the copyright holder. To view a copy of this license, visit http://creativecommons. org/licenses/by/4.0/.
\end{abstract}

(c) The Author(s) 2021 